\title{
Immigrants, Precarious Workforce as a Structural Necessity of Modern Global Capitalism
}

\author{
LUKASZ RĄB \\ Wydziat Organizacji i Zarzadzania, Katedra Stosowanych Nauk Społecznych, \\ Politechnika Ślaska, \\ ul. Roosevelta 26, 41-800 Zabrze, \\ E-mail:lukasærab@gmail.com
}

\begin{abstract}
This article focuses on the socio-economic aspects of migration and migrants - economic refugees. The author presents the migrants as a precarious workforce, which is an indispensable part of modern global capitalism. In this article, the author points out that among the many factors influencing migration, the economic ones play the most crucial role. Forces released by the neo-liberal paradigm led to the global economic and social tensions. This is due to the fact that the market has become the only regulator of economic and social relations. This article is not another critique of neo-liberal doctrine, advocating for replacing capitalism by "something else." The author believes, similarly to John Gray, that what we need is a consensus between the states on different models of capitalism, as there are different cultures.
\end{abstract}

Key words: migrants, migration, precariat, precarization of work, globalisation, neoliberalism, civilization changes

\section{INTRODUCTION}

Regardless of the reasons why people leave their homeland, whether it is war, natural disasters, political persecution, or famine, it is always about improving the human condition. The latter is inextricably linked with work. Work is one of the main topics addressed by social sciences. In ancient times, it was perceived negatively and performed mainly by slaves. It was not a privilege, but a duty. At least since the industrial revolution work is desirable, and its absence excludes from 
full participation in society. Unemployment has become one of the basic social, economic and political problems.

Migration is not something specific only for our times. Migration is as old as our civilization. Periods of intense migratory movement of great historical significance have occurred both in the history of our civilization, as well as in other parts of the world at different times. The problem, which we are currently experiencing, is the influx of people from the Middle and Far East and North Africa to Western Europe and from Latin America to the United States, ${ }^{1}$ people ready to work for a significantly lower salary than the labor market is able to offer, is the culmination of long-term processes. Zygmunt Bauman in a recent essay "Strangers at Our Door," wrote that such a huge increase in the number of refugees is a side effect of misguided and disastrous expeditions to Afghanistan and Iraq. These interventions, according to Bauman, resulted in:

conversion of dictatorial regimes in the continuous spectacle of tyranny and madness of violence - encouraged and goaded by unchained arms trade, gaining momentum through profit-hungry defense industry, which is done with the tacit (...) the consent of the governments focused on the GDP growth (Bauman 2016, 12).

The problem of the economic migrations is a consequence of the neo-liberal economic policy, focusing on increasing the exploitation of workers and the reversal of redistribution (Wielgosz 2016, 3). This has become possible thanks to processes such as liberalization, commercialization and deregulation. In addition, broadening the field of action of the private sector, with a simultaneous withdrawal of the state, which itself is exempt from responsibility for the functioning of the sphere of social services also plays a role. "Recovered" in this way, deficit spending can be used to further increase the global competitiveness of private producers (Polak, Polak 2013, 11-20).

The neo-liberal paradigm brought about global economic and social tensions. This is due to the fact that the market has now become a major factor in regulating the economic and social relations, and from among the many factors contributing to migration, it is economic factors that exert the strongest impact.

\footnotetext{
1 The problem of migration, of course, does not apply only to the above mentioned directions. Migrations from poor countries to rich ones are roughly one-third of total global migration rate. The rest are the directions from rich countries to other rich countries and from the poor countries to other poor ones. Western countries are not the only rich countries, which attract immigrants, and where refugees become members of the precariat. Foreigners are working in Qatar in tragic conditions. Most of this two million group are construction workers and as every foreigner in Qatar they are subjected to the kafala system. Under the guise of a system to monitor migrants, which is the kafala system, lies half-slave system that deprives workers of all rights, even such as a change of employer before the expiry of two years or the possibility of returning to their homeland. For that, they need the original version of their residency papers, which are often held by the employer. Not to mention the starvation wages and inhuman working and living conditions (Garcia 2016, 14), (The Economist, 2013).
} 
Migrants play a key role in capitalism as both a "reserve army of labor," and a means to increase profit. ${ }^{2}$ Migrants thus provide global job security and are one of the most important reasons for its enlargement. Guy Standing, when describing new social phenomena, recently revived the concept of "precariat," which defines migrants as "infantry of the whole process of precariousness" $(2014,190)$ of work. Precarious work is, according to some, a structural necessity of modern global capitalism (Žižek 2016, 126-131).

\section{WHAT IS PRECARIAT?}

Precariat is a typical condition of the post Fordian model of production, which does not hold traditional class divisions and is a symptom of global neo-liberalism. Many commentators of late capitalism such as Loïc Wacquant, see in precarious work a common condition linking the fate not only of numerous representatives of different, classically understood, social classes, but also the workers / employees of the global North and South. Although the number of publications on the precariat is quite large, ${ }^{3}$ according to Jaroslaw Urbański, this term does not yet have a clear definition. Antonio Negri is a co-author of one of them. It says, that precariat is:

an another step, after proletarianization, i.e. the subordination to the regime of wage labor as such, of the development of capitalist relations of production, and at the same time, a regression of the social achievements of working class from the second half of the $20^{\text {th }}$ century (Ratajczak, Sowa 2012, 517-518; own transl.).

Standing, like Negri, links the precariat with the end of the welfare state, which follows the "glorious 30 years" after the war. According to Standing, precarious workers are primarily people deprived of the seven types of work-related securities, which were gained by the Social Democrats after the WW2. Precarious workers suffer from a lack of:

- Security on the job market

- Security of employment

- Workplace safety

- Work security

- Security of skills reproduction

\footnotetext{
2 Already in 1845 Federick Engels wrote: "English manufacture must have, at all times save the brief periods of highest prosperity, an unemployed reserve army of labor, in order to produce the masses of goods required by the market in the liveliest months" (Engels 1962).

3 It is characteristic that the subject of precarious work is elaborated mostly by the activists of social movements and academics from post-industrial societies of Europe, USA and Japan, where Fordism was strongly developed. Kathleen Millar, an anthropologist from Brazil points it out in the article: The Precarious Present: Wageless Labor and Disrupted Life in Rio de Janeiro, Brazil, as does Anne Allison. Therefore, in addition to the allegation of ambiguity of the definition of "precarious work", which Urbanski set forth, we can point out the narrow perspective of research limited only to Western countries. However, precarious work, as proved by the mentioned authors, but also by Wacquant and Jean and John L. Comaroff, Ned Rossiter or Brett Neilson is present everywhere (Millar 2014, 32-53).
} 
- Income security

- Representation security (Standing 2014, 49).

Apart from the withdrawal of the welfare state, the emergence of precariat was greatly influenced by a change in management, namely the transition from Taylorism to Toyotism, which took place in the 1980's. The organizational changes started at that time were implemented to make the worker less "alienated" thanks to shifting a part of his/her responsibility. However, autonomy and responsibility did not improve worker's conditions, but as it was pointed by Luc Boltanski and Ève Chiapello in The New Spirit of Capitalism workers became objects of a new form of exploitation. Autonomy and responsibility:

were obtained at the price of a reduction in the protections enjoyed by wage-earners at the start of the period, which derived not only from economic conditions but also from a balance of power that was temporarily favourable to them. (...) autonomy was exchanged against security, to the point where it is often a forced, involuntary autonomy, difficult to equate with freedom (Boltanski, Chiapello 2007, 430).

According to Boltanski and Chiapello $(2007,430)$ a decrease in security is "the most striking of the forms of opression," which indirectly is a result of new form of employment (fix term contracts, etc.). Meanwhile, the situation of workers who have not yet been precarized became paradoxical. The autonomy granted in exchange for accepting more responsibility and modification of working methods has made employees more autonomous, but at the same time more incapacitated (Boltanski, Chiapello 2007, 430). This is due to changes in the modes of control in the management process:

Given that enhanced autonomy is accompanied by a growth in self-control and team work, with a corresponding reinforcement of peer-group control, it is even possible that workers are more highly controlled than they were previously (Boltanski, Chiapello 2007, 431).

There was a shift from a "surveillance society" in the sense of Foucault to "audit society," the evolution of techniques of control of "direct supervision" into the "control of control" (Boltanski, Chiapello 2007, 432).

\section{MIGRATORY COMPETITION}

Returning to economic refugees enlarging the ranks of precarious workers, they are the price, notes Slavoj Žižek (2016, 126-131), we pay for a globalized economy, in which goods - not people - are allowed to freely migrate. An extreme, but relevant example, which shows these pathologies are sweatshops. These are manufacturing plants, which are very difficult or dangerous working

4 This term (audit society) was introduced by Michael Power, professor of London School of Economics and Political Science, who was quoted by Boltanski and Chiapello in the above mentioned work. 
conditions, where workers are deprived from protection rights and are not covered by formal labor relations. In reality, sweatshops are places, where people, mostly women, are forced into slave labor. Wages are extremely low or workers do not receive a payment. This calls to mind the images of factories from the turn of the 20th century from the UK or USA, when workers' rights were almost non-existent. Although sweatshops are characteristic to the Third World, such places can be also found nowadays in developed countries. A lot has been written recently in the Polish press about construction workers from North Korea who build a housing estate in Warsaw. ${ }^{5}$ Their hourly rate is much lower than the average in this sector in Poland, and also their earnings are mostly confiscated (indirectly) by the Korean regime. The question is whether in the case of the Korean builders we have to deal with migrants or whether they are simply a product offered by the North Korean government?

Sweatshops, which are probably the most precarized workplaces, have their defenders. They claim, that people choose to work in sweatshops, because they offer way better working conditions in comparison with primitive farming. They also claim, that sweatshops are the first step in the technological development of poor countries and that this is their chance for economic development. This can be of course claimed, if we assume that there is no other way.

Capital, as can be seen eagerly greets migration. It provides it with a cheap labor force. As noted by Dominic Casciani, quoted by Z. Bauman in the aforementioned essay, British employers have learned to acquire cheap labor, using special employment agency whose sole job is to locate and recruit undemanding and often desperate foreign workers (Bauman, 10). Governments take also advantage of immigrants. The latter are interested in the economic refugees who left their countries to look for employment. There is something called migratory competition. As mentioned, at the beginning, the current migratory crisis is connected with the influx of people from the Middle East and North Africa to Western Europe. However, this problem has also its inner European dimension.

Hungarian philosopher Gáspár Miklós Tamás claims that for countries such as Hungary it is important to actually stop refugees, so they do not compete with them for wealth from the West $(2016,6-7)$. Although they call it a bad joke, when we have a closer look at the numbers, this joke becomes quite real. For example, a few years ago the population of Romania was twenty three million people, today it is eighteen million. Over the past two years 600000 Hungarians have left the country for the UK and Germany, and the majority of them were young, qualified people with university diplomas. If in the West the new refugees replaced them, it would mean an

\footnotetext{
5 This is not the first case when slaves from North Korea were on the Polish labor market. Earlier they filled the gap left by welders who left the Gdansk shipyard in Poland (Tomański 2016), (Chrzan, Kowalski 2006).
} 
economic catastrophe for Eastern Europe. This would be because the aging population, among others, in Poland, would lose their source of income, that is family members, who work in the western countries (Tamás 2016, 6-7). Only in 2015, Poles working abroad sent over sixteen billion Polish zloty to Poland, ${ }^{6}$ which boosted consumption in the county, and of course it decreased the unemployment rate (Maciejewicz 2016). This is why governments, especially in the Visegrad Group, use anti-migratory social moods that point to refugees as an economic problem and a threat to national identity and security.

I would like to note at this point how dangerous the outflow of social energy in the form of economic refugees, not only from Eastern Europe, can be. A historical example is Spain in times of colonizing South America, when it coped with unemployment among the nobility. However, weakened by the social potential outflow, Spain collapsed (Moczulski 2016). In this place it is worth mentioning data from the report Economic Migrations of Poles, conducted by Work Service in 2015. This report shows, that over 12 months, every fifth active participant in the job market in Poland considers economic emigration. This means, that 1.25 million Poles are ready to leave the county and $63 \%$ of them are under the age of 35 years old (Work Service 2015).

\section{SUMMARY}

In closing, let me reiterate that economic migration and refugees, which constitutes the backbone of precariat, are an integral part of global capitalism. They are, as many commentators of contemporary capitalism claim, its structural necessity. Although the neo-liberal doctrine, which distorted the values of liberalism, is not close to me, and I do not think that capitalism should be replaced by "something else." I think, similarly to John Gray $(2015,69)$, that a change of capitalism would not be enough - what is needed is a consensus between countries, a realization that there are different models of capitalism and different cultures. What is certain is that various states and regions are becoming increasingly linked, just as it is certain that they will never accept a single economic system. Economies reflect family life, religious beliefs or geopolitical conditions. It is important that the processes of globalization, which is the source of Western capitalism, take these factors into account. This is possible only when the global management ${ }^{7}$ accepts the diversity of political and economic systems. The processes of globalization, which cause mainly unification, must also bring the freedom, but not that, which is proposed by neo-

\footnotetext{
${ }^{6}$ According to the National Polish Bank, between 2004-2013, 41.6 billion EUR were placed sent to Poland from Poles working abroad. To compare, European Funds from this period are 108 billion EUR (Chmielewska 2015).

7 Behind the concept of "global leadership" is the American empire, which, according to J. Gray is the only preferred and available form of global governance. However, it may not be as durable as Pax Britannica.
} 
liberal capitalism. Freedom in the neo-liberal context has been limited to the entrepreneurship, which guarantees, as put by Karl Polanyi:

the fullness of freedom for those whose income, leisure, and security need no enhancing, and a mere pittance of liberty for the people, who may in vain attempt to make use of their democratic rights to gain shelter from the power of the owners of property (Polanyi 2001, 265).

We need globalization, which source is not imperialistic ambitions, nationalism, hatred of immigrants, religious fundamentalism and modern slavery (Wallerstein, Collins, Mann, Derluguian, Calhoun 2015, 218). Perhaps the solution suggested by Alexander Kojève (2015, 516), that Western capitalism should be less "taking" and more "giving" - less exploitation and wiser investments.

\section{REFERENCES}

Bauman Z. (2016). Obcy u naszych drzwi. Warszawa: PWN.

Boltanski L., Chiapello È. (2007). The New Spirit of Capitalism. Transl. by G. Elliot. London: Verso.

Chmielewska, I. (2015). Transfery z tytułu pracy Polaków za granica w świetle badań Narodowego Banku Polskiego. Warszawa: Instytut Ekonomiczny.

Chrzan, M. Kowalski, M. (2006). W Stoczni Gdańskiej pracują niewolnicy z Korei. Gazeta Wyborcza, March 24, 2006.

The Economist. (2013). The Middle East's Migrant Workers. Forget about Rights. The Economist, August 10, 2013. Retrieved from: http://www.economist.com/news/middle-east-and-africa/21583291-attemptsimprove-lot-migrants-working-middle-east-are-unlikely (15.05.2016).

Engels, F. (1962). The Condition of the Working Class in England, In: K. Marx, F. Engels, On Britain. Moscow: Foreign Languages Publishing House.

Garcia, D. (2016). Niewolnicy XXI w. w Katarze. Le Monde Diplomatique, 6, 14-17.

Gáspár, M. T. (2016). Znaczenie kryzysu migracyjnego. Le Monde Diplomatique, 3, 6-7.

Gray, J. (2015). Herezje. Przeciwko postępowi i inne eseje. Wrocław: Wektory.

Kojève, A. (2014). Kolonializm z perspektywy europejskiej. Kronos, 4, 5-16.

Maciejewicz, P. (2016). Za granicą Polacy zarabiają krocie. Wiemy, gdzie najwięcej. Wyborcza.pl, May 10, 2016. Retrieved from: http://wyborcza.biz/biznes/1,147666,20046597,za-granica-polacy-zarabiaja-krociewiemy-gdzie-najwiecej.html\#BoxBizLink (15.05.2016). 
Millar, K. (2014). The Precarious Present: Wageless Labor and Disrupted Life in Rio de Janeiro, Brazil. Cultural Anthropology, 29(1), 32-53.

Moczulski, L. (2016). Potencjał polityki światowej. Rozmowa Marcina Celińskiego z Leszkiem Moczulskim. Liberté, March 23, 2016. Retrieved from: http://liberte.pl/potencjal-polityki-swiatowej/ (15.05.2016).

Polak, E. Polak, W. (2013). Ekonomizacja nierynkowych dziedzin życia i jej konsekwencje. Współczesna Gospodarka, 4(1), 11-20

Polanyi, K. (2001). The Great Transformation. The Political and Economic Origins of Our Time. Boston: Beacon Press.

Ratajczyk, M., Sowa, J. (2012). Słownik pojęć. In: Rzeczy-pospolita. Poza własność prywatna i dobro publiczne. (pp. 511-522). Transl. by Praktyka Teoretyczna. Kraków: Wydawnictwo Korporacji Ha!art.

Standing, G. (2014). Prekariat. Nowa niebezpieczna klasa. Warszawa: Wydawnictwo Naukowe PWN.

Tomański, R. (2016). Polska w budowie - dzięki niewolnikom z Korei Płn. Może harują właśnie przy twoim mieszkaniu? Wyborcza.pl, April 12, 2016. Retrieved from: http://wyborcza.pl/1,87648,19903681,polska-w-budowie-dzieki-niewolnikom-zkorei-pln-moze-haruja.html (15.05.2016).

Wallerstein, I. Collins, R. Mann, M. Derluguian, G. Calhoun, C. (2015). Czy kapitalizm ma przyszłość? Warszawa: Wydawnictwo Akademickie Dialog.

Wielgosz, P. (2016) .Uchodźcy: kryzys którego nie było. Le Monde Diplomatique, 3, 3.

Work Service (2015). Migracje zarobkowe Polaków. Raport Work Service S.A. Retrieved from: http://www.workservice.p1/Centrum-prasowe/Informacje-prasowe/EkspertHR-komentuje/Az-1-2-mln-Polakow-zdecydowanych-na-emigracje-zarobkowa (15.05.2016).

Žižek, S. (2016). Norwegia nie istnieje. Krytyka Polityczna, 43, 126-131. 